\title{
A Facile Synthesis of 2-Chloro-5,7-dihydro-pyrrolo[3,4-b]pyridine-6-carboxamidine, an Annulated Nicotinoid
}

\author{
Kwang-Nym Cho, Su-Jin Park, and Kee-In Lee* \\ Bio-Organic Science Division, Korea Research Instinte of Chemical Technology. P.O. Box 107. Yusong. Daejeon 305-600, Korea \\ Received March 10, 2004
}

Key Words : Chloropyridine, $n \Lambda \mathrm{ChR}$, Conformational rigidity, $\pi$-Cation interaction, Dihydropyrrolopyridine

The chloropyridine moiety confers high potency to several types of analgesics and insecticides acting at nicotinic acetylcholine receptors (nAChRs). This includes (-)epibatidine 1, isolated from the skin of Scuadorian poison frog Epipedobates tricolor. ${ }^{1}$ The pharmacological profiles of 1 show the exceptionally strong analgesic activity and the high affinity for $n A C h R$. Recent advances in the search for nAChR ligands include the discovery of ABT-594 2 . currently in development for the treatment of Parkinson's and Alzheimer's disease. ${ }^{2}$ Whereas, imidacloprid $\mathbf{3}$, one of the most important synthetic insecticides, acts selectively at the insect versus the mammalian $\mathrm{nAChR}{ }^{3}$

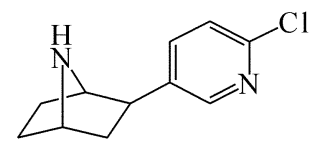

1

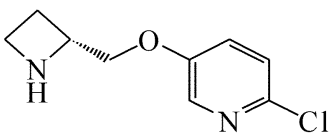

2<smiles>O=[N+]([O-])C1NCCN1Cc1ccc(Cl)nc1</smiles>

3

The $\pi$-cation interaction plays an essential role in the central nervous system, as a number of neurotransmitlers contain cationic moieties. ${ }^{4.5} \wedge$ mounting evidence indicates the significance of the $\pi$-cation interactions in the binding of acetylcholine and related ligands to acetylcholine esterase, nicotinic and muscarinic acetylcholine receptors, and other $G$ protein-coupled receptors. The site-directed mutagenesis analysis of $n A C h R$ provides the evidence that the highly conserved aromatic residues are possibly involved in ligand binding with a cationic center, protonated $\mathrm{sp}^{3}$ nitrogen. Indeed, the deletion or replacement of these amino acids leads to signilicant diminution ol ligand binding aflinity.

$\Lambda$ s epibatidine only contains one rotable bond, its freedom is severely restricted. Therelore, a special attention has been paid to the preparation of conformationally constrained nicortinoids as attractive candidates for selective $n \Lambda C h R$

"Corresponding Author. Tel: +82-42-860-7186; Fax: +82-42860-7।60; e-mail: kilee(ov krict.re.kr ligands. Thus, we designed an annulated niocotinoid, which have a chloropyridinyl nitrogen and a cationic moiety suitably placed on dilyydropyrrolopyridine skeleton in order to potentially interact with the receptor sites through hydrogen bonding and electrostatic interaction, respectively. Here, we wish to report a facile synthesis of 2-chloro-5.7dihydro-pyrrolo[3,4-b]pyridine-6-carboxamidine 12 from 2chlorocuinoline 4 , ln our best knowledge, a synthesis of 2chloro-6.7-dihydro-5H-pyrrolo[3,4- 6 ]pyridine 10 has not been reported previously.

It is envisioned that a facile synthesis of 6-chloro-pyridine2,3-dicarboxylic acid 5 would offer the most concise synthetic route to the target molecule, as shown in Scheme 1. Despite a numerous advances in the dihydropyrrolopyridine chemistry, the synthesis of halide-containing one is quite rare, presumably, due to the lack of availability of halidecontaining quinolinic and cinchomeronic acid precursors. Although there are some methods for the preparation of halide-containing pyridine dicarboxylic acids, a facile and reliable preparation of such compounds is poorly documented. $^{6}$

It is well known that the ruthenium-catalyzed oxidation of aromatic rings would offer a very efficient and simple route to carboxylic acid. ${ }^{\overline{ }}$ Thus, 2-chlorocpuinoline 4 was reacted with ruthenium tetroxide, generated in sizu from $\mathrm{RuCl}_{3}$ and $\mathrm{H}_{5} \mathrm{IO}_{6}$ in a biphasic conditions $\left(\mathrm{CCl}_{4}, \mathrm{CH}_{3} \mathrm{CN}, \mathrm{H}_{2} \mathrm{O}\right)$. Next. the acid 5 was treated with methyl iodide and cesium carbonate in DMF to give the ester $6 .{ }^{8}$ Surprisingly, a problem was encountered in the reduction of 6 . In spite of many precedences, ${ }^{9}$ an attempted reduction of 6 with $\mathrm{BH}_{3-}$ [HF or of 5 with $\mathrm{LiAlH}_{4}$ was unsuccessful. In both reaction conditions, the reaction mixtures turned reddish and the starting materials were completely decomposed. After several trials, we found in situ generated calcium borohydride reduction of 6 cleanly afforded the diol 7 in $88 \%$ yield. ${ }^{10}$ The remaining steps were quite straightforward. By adding of thionyl chloride, 7 was readily converted to the halide 8 in $85 \%$ yield, and subsequent substitution of $\mathbf{8}$ with $p$ toluenesulfonamide and sodiun hydride in DMF furnished the tosylate 9 in $57 \%$ yield. Finally, the deprotection of 9 was accomplished with hydrogen bromide $(30 \mathrm{wt}$ \% solution in acetic acid) in the presence of phenol to afford 2-chloro6.7-dihydro-5//-pyrrolo[3,4-b]pyridine 10 in nearly quantitative yield.

In a recent report, Goodman et $a l$. introduced $N, N^{\prime}$-di-Boc- 
<smiles>Clc1ccc2ccccc2n1</smiles><smiles>[R]OC(=O)c1ccc(Cl)nc1C(=O)O[R]</smiles>

4

$$
\begin{array}{rl}
5 \mathrm{R} & =\mathrm{H} \\
\mathrm{b} & 6 \mathrm{R}=\mathrm{Me}
\end{array}
$$<smiles>[R]Cc1ccc(Cl)nc1C[R]</smiles>

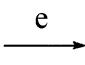

$$
\begin{aligned}
\mathrm{d} \longrightarrow \mathrm{R} & =\mathrm{OH} \\
\mathbf{8} \mathrm{R} & =\mathrm{Cl}
\end{aligned}
$$<smiles>[R]NC(=[R])N1Cc2ccc(Cl)nc2C1</smiles>

$\begin{aligned} \mathrm{h} \longrightarrow \mathrm{11} \mathrm{R} & =\mathrm{Boc} \\ 12 \mathrm{R} & =\mathrm{H}\end{aligned}$

Scheme 1. (a) RuCl${ }_{3} . \mathrm{H}_{5} \mathrm{lO}_{0}$. $\mathrm{MeCN}-\mathrm{CCl}_{4}-\mathrm{H}_{2} \mathrm{O}$ : (b) $\mathrm{Mel}, \mathrm{Cs}_{7} \mathrm{CO}_{3}$.

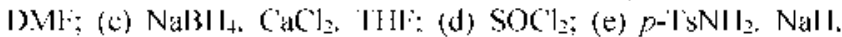

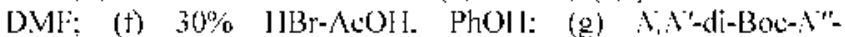
trifly guanidine. $\mathrm{Et}_{3} \mathrm{~N}$. $\mathrm{CH}_{2} \mathrm{Cl}_{2}$ : (h) TFA. Et $\mathrm{SiH}_{\mathrm{SiH}}$

$N^{\prime \prime}$-triflylguanidine" which was utilized to guanidinylate primary and secondary amines, and alcohols. Thus, the reaction of 10 with $N, N^{\prime}$-di-Boc- $N^{\prime \prime}$-triflylguanidine produced $N_{1} N^{\prime \prime}$-di-Boc- $N^{\prime \prime}$-guanidine 11, which was easily converted to the target compound $\mathbf{1 2}$ with trifluoacetic acid in the presence of triethylsilane. The guanidine moiety have a strongly basic character which fully protonated under physiological conditions. Thereby, we reasoned the positive charge imposed on the molecule has a chance to form a $\pi$ cation interaction between the ligand and $\mathrm{nAChR}$.

In conclusion, a highly efficient synthesis of 2-chloro-5,7dihydro-pyrrolo[3,4-b]pyridine-6-carboxamidine 12 , an annulated nicotinoid, has been accomplished starting from 2-chloroquinoline 4 . It is noteworthy that the title compound contains chloropyridinyl nitrogen and a cationic moiety suitably placed on dihydropyrrolopyridine skeleton in order to potentially interact with nAChR. This work may offer a substantial method for the synthesis of halide-containing 6,7-dihydro-5 $H$-pyrrolo[3,4-b]pyridine and 2,3-dihydro- $1 H$ pyrrolo[3,4-c]pyridine, which were difficult to obtain. Currently, we are investigating the binding affinity of a series of annulated nicotinoids to $n A C h R$ and the result will be reported in due course.

\section{Experimental Section}

6-Chloro-pyridine-2,3-dicarboxylic acid (5). A roundbottomed flask was charged with acetonitrile $(60 \mathrm{~mL})$, carbon tetrachloride $(60 \mathrm{~mL})$, water $(90 \mathrm{~mL})$, periodic acid (99.0 g. $434 \mathrm{mmol}$ ), and ruthenium(III) trichloride hydrate
(152.8 $\mathrm{mg}, 0.74 \mathrm{mmol}$ ). The flask contents were vigorously stirred until both phases became clear. To the flask added 2chloroquinoline (4) $(5.0 \mathrm{~g} .30 .56 \mathrm{mmol})$ in portions, and the reaction mixture was stirred for $4 \mathrm{~h}$. keeping the temperature within the range of $25-40^{\circ} \mathrm{C}$ by the control of the stirring speed with an ice-water bath, until no starting material was detected by $\mathrm{ILC}$. The reaction mixture was cooled to $0^{\circ} \mathrm{C}$, and ether $(60 \mathrm{~mL})$ was added with vigorous stirring for 10 min. The organic layer was separated and the aqueous extracted with ether. The combined organic layers were washed with brine, dried over magnesium sulfate, and evaporated to yield an oil which was crystallized from dichloromethane-hexane to give $5(4.62 \mathrm{~g} .75 \%)$ as a solid. mp 151-152 "C (Lit." mp 152-154 "C); 'H NMR (DMSO-d ) $\delta 8.53(\mathrm{~d}, J=8.3 \mathrm{~Hz}, \mathrm{lH}) .7 .70(\mathrm{~d}, J=8 . \mathrm{l} \mathrm{Hz}, \mathrm{lH}) ;$ EIMS $m /=$ (rel intensity) $202\left(\mathrm{M}^{+}, 2\right), 157$ (45), 139 (100), l I l (33).

6-Chloro-pyridine-2,3-dicarboxylic acid dimethyl ester (6). Methyl iodide (24.2 g. $170.6 \mathrm{mmol}$ ) and cesium carbonate $(27.79 \mathrm{~g} .85 .3 \mathrm{mmol})$ were added to a solution of 5 $(5.73 \mathrm{~g} .28 .4 \mathrm{mmol})$ in DMF $(100 \mathrm{~mL})$ and the reaction mixture was allowed to stir for overnight. The mixture was diluted with ethyl acetate. The combined organic layers were washed successively with water, dried over magnesium sulfate and evaporated under reduced pressure to give an oily residue. The residue was purified by flash chromatography on silica gel with ethyl acetate/hexane $(1: 7)$ as the eluent to give $5.28 \mathrm{~g}(81 \%)$ of 6 as a solid. $\operatorname{mp~} 46-47{ }^{\circ} \mathrm{C}$; ${ }^{1} \mathrm{H}$ NMR $\left(\mathrm{CDCl}_{3}\right) \delta 8.14(\mathrm{~d}, J=8.1 \mathrm{~Hz}, \mathrm{lH}), 7.49(\mathrm{~d}, J=8.1 \mathrm{~Hz}, \mathrm{lH})$, $3.96(\mathrm{~s}, 3 \mathrm{H}), 3.93(\mathrm{~s}, 3 \mathrm{H}),{ }^{13} \mathrm{C}$ NMR $\left(\mathrm{CDCl}_{3}\right) \delta 165.1,164.2$. $153.8,151.3,140.1,125.5,124.0 .52 .9 .52 .8:$ EIMS $m / z$ (rel intensity) $231\left(\mathrm{M}^{-}, \mathrm{I}\right), 229\left(\mathrm{M}^{-}, 4\right), 198(34), 140(35), 102$ (100). 76 (88); Anal. Calcd for $\mathrm{C}_{2} \mathrm{H}_{8} \mathrm{ClNO}_{4}: \mathrm{C}, 47.08 ; \mathrm{H}$. $3.51 ; \mathrm{N}, 6.10$. Found: C. 47.12; H, 3.49; N. 6.02 .

(6-Chloro-2-hydroxymethyl-pyridin-3-yl)-methanol (7). Calcium chloride (1.73 g. $15.6 \mathrm{mmol})$ and sodium borohydride (1.18 9.31.2 mınol) were stirred in 'THF (30 mL) at room temperature for $\mathrm{l} h$. A solution of 6 (1.79 g. 7.82 $\mathrm{mmol})$ in $\mathrm{THF}(5 \mathrm{~mL})$ was added dropwise to this hydride suspension. The reaction mixture was allowed to stir for $13 \mathrm{~h}$ at room temperature. The excess hydride was quenched with methanol and potassium carbonate was added to this residue. The organic layer was decanted and the residual solid washed repeatedly with THF. The combined organic layer was dried over sodium sulfate and concentrated to yield an oily residue. The residue was purified by flash chromatography on silica gel with ethyl acetate hexane $(\mathrm{I}: \mathrm{l})$ as the eluent to give $1.2 \mathrm{~g}(88 \%)$ of 7 as a solid, mp $37-39^{\circ} \mathrm{C}$; ${ }^{\prime} \mathrm{H}$ NMR $\left(\mathrm{CDCl}_{3}\right) \delta 7.70(\mathrm{~d}, J-8.1 \mathrm{~Hz}, 1 \mathrm{H}), 7.25(\mathrm{~d}, J-8.0$ $\mathrm{Hz}, 1 \mathrm{H}), 4.67(\mathrm{~d}, J-13.8,4 \mathrm{H}) ;{ }^{13} \mathrm{C}$ NMR $(\mathrm{CDCl}) \delta 157.4$. 149.2, 139.0, I32.3, 123.I, 62.3, 60.5; ElMS $m / s$ (rel intensity) 172 (3). $155(100), 127(83) .91$ (40).

6-Chloro-2,3-bis-chloromethyl-pyridine (8). Thionyl chloride (5 $\mathrm{mL}, 68.8 \mathrm{mmol}$ ) was slowly added to a solution of $7(1.10 \mathrm{~g} .6 .36 \mathrm{mmol})$ in dichloromethane $(10 \mathrm{~mL})$ at $0^{\circ} \mathrm{C}$. for $30 \mathrm{~min}$ and the reaction mixture was allowed to stir at room temperature for overnight. The mixture was concentrated under reduced pressure to give an oily residue. The 
residue was purified by flash chromatography on silica gel with ethyl acetate/hexane $(1: 3)$ as the eluent to give $37 \mathrm{mg}$ $(85 \%)$ of $8,{ }^{1} \mathrm{H}$ NMR $\left(\mathrm{CDCl}_{3}\right) \delta 7.65(\mathrm{~d}, J=8.2 \mathrm{~Hz}, \mathrm{lH})$. $7.26(\mathrm{~d}, J=8.2 \mathrm{~Hz}, \mathrm{lH}) .4 .68(\mathrm{~s}, 2 \mathrm{H}) .4 .65(\mathrm{~s}, 2 \mathrm{H}),{ }^{13} \mathrm{C} \mathrm{NMR}$ $\left(\mathrm{CDCl}_{3}\right) \delta 155.4,150.7,141.1 .131 .2 .124 .8,43.6 .41 .0$ : EIMS $m z$ (rel intensity) $215\left(\mathrm{M}^{-}, 2\right) .209\left(\mathrm{M}^{-} .49\right) .174$ (100). 138 (42); Anal. Calcd for $\mathrm{C}_{7} \mathrm{H}_{6} \mathrm{Cl}_{3} \mathrm{~N}: \mathrm{C}, 39.94: \mathrm{H}$. 2.87: N. 6.65. Found: C. 40.45: H. 2.71 ; N. 6.29.

2-Chloro-6-(toluene-4-sulfonyl)-6,7-dihydro-5 $\mathrm{H}$-pyrrolo[3,4-b]pyridine (9). $p$-Toluenesulfonanide (361 mg. 2.1 $\mathrm{mmol}$ ) was added in portions to a suspension of $95 \%$ sodium hydride (100 mg. $4.2 \mathrm{mmol})$ in DMF (15 mL) at room temperature for $1 \mathrm{~h}$. To this suspension was added a solution of $8(370 \mathrm{mg}, 1.8 \mathrm{mmol})$ in DMF $(10 \mathrm{~mL})$ at room temperature for $1 \mathrm{~h}$ and then the reaction mixture was heated at $70^{\circ} \mathrm{C}$ over $\mathrm{l} \mathrm{h}$. The mixture was diluted with ethyl acetate. The combined organic layers were washed successively with water. dried over magnesium sulfate and evaporated under reduced pressure to give an oily residue. The residue was purified by flash chromatography on silica gel with ethyl acetate/hexane $(1: 3)$ as the eluent to give $308 \mathrm{mg}(57 \%)$ of 9 as a solid. mp $189-190{ }^{\circ} \mathrm{C}:{ }^{1} \mathrm{H} \mathrm{NMR}\left(\mathrm{CDCl}_{\hat{3}}\right) \delta 7.69(\mathrm{~d}, J=$ $8.2 \mathrm{~Hz} .2 \mathrm{H}), 7.39(\mathrm{~d}, J=8.0 \mathrm{~Hz} . \mathrm{HH}), 7.26(\mathrm{~d}, J=8.6 \mathrm{~Hz}$. $2 \mathrm{H}), 7.12(\mathrm{~d} . J=8.4 \mathrm{~Hz}, 1 \mathrm{H}), 4.54(\mathrm{~s}, 4 \mathrm{H}), 2.34(\mathrm{~s}, 3 \mathrm{H}):{ }^{13} \mathrm{C}$ NMR $\left(\mathrm{CDCl}_{3}\right) \delta$ 157.6. 151.4. 144.1, 133.3, 130.0, 128.7. 127.6, 127.5. 123.1. 53.4, 51.7. 21.5; EIMS $m z$ (rel intensity) $308\left(\mathrm{M}^{+} .20\right) .153(100) .91(75) .65(28)$.

2-Chloro-6,7-dihydro-5 $H$-pyrrolo $[3,4-b]$ pyridine (10). A solution of $9(360 \mathrm{mg}, 1.2 \mathrm{mmol})$ in $30 \% \mathrm{HBr}$ in acetic acid $(8.4 \mathrm{~mL})$ and phenol $(0.3 \mathrm{~mL}, 3.4 \mathrm{mmol})$ was refluxed for $0.5 \mathrm{~h}$ and then the solution was evaporated to dryness to yield a residual solid. The solid was collected by filtration. washed with diethyl ether. and dried in victo to yield 264 mg $(96 \%)$ of 10 , mp 194-195 ${ }^{\circ} \mathrm{C}:{ }^{1} \mathrm{H}$ NMR $\left(\mathrm{CDCl}_{3}\right) \delta 7.59$ $(\mathrm{d}, J=8.1 \mathrm{~Hz}, 1 \mathrm{H}), 7.26(\mathrm{~d}, J=8.1 \mathrm{~Hz}, 1 \mathrm{H}), 5.83$ (s. $2 \mathrm{H})$. 4.43 (d. $J=8.7 \mathrm{~Hz} .4 \mathrm{H}), 4.54$ (s. $4 \mathrm{H}) ;{ }^{13} \mathrm{C} \mathrm{NMR}\left(\mathrm{CDCl}_{3}\right) \delta$ $160.3,150.5 .132 .9,132.8,122.1 .52 .5,50.5$ : HRMS Calcd for $\mathrm{C}_{7} \mathrm{H}_{8} \mathrm{ClN}_{2}:$ 155.0376, Found: 155.0376 .

[tert-Butylcarbonylimino-2-chloro-5,7-dihydro-pyrrolo[3,4-b]pyridene-6-ylmethyl]-carbamic acid tert-butyl ester (11). The compound $10(150 \mathrm{mg} .0 .64 \mathrm{mmol})$ was added to a solution of $N, N^{\prime}$-di-Boc- $N^{\prime \prime}$-trifly'lguanidine $(0.30$ g. $0.78 \mathrm{mmol}$ ) and triethylamine $(0.18 \mathrm{~mL} .1 .3 \mathrm{mmol})$ in methylene chloride $(4 \mathrm{~mL})$. The reaction mixture was allowed to stir at room temperature for $2 \mathrm{~h}$. After the reaction was complete. the solution was diluted with methylene chloride and washed with $2 \mathrm{M}$ sodium bisulfate. saturated sodium bicarbonate. and brine. The organic extract was dried over sodium sulfate and the solvent was removed under reduced pressure. The residue was purified by flash chromatography on silica gel with ethyl acetate/hexane $(1: 7)$ as the eluent to give $226 \mathrm{mg}(90 \%)$ of $11 . \mathrm{mp} 193^{\circ} \mathrm{C}$ : ${ }^{1} \mathrm{H} \mathrm{NMR}\left(\mathrm{CDCl}_{3}\right) \delta 7.54(\mathrm{~d} . J=8.1 \mathrm{~Hz} .1 \mathrm{H}) .7 .25(\mathrm{~d} . J=8.1$
Hz. 1 H). 4.97 (d. $J=8.7 \mathrm{~Hz} .4 \mathrm{H}), 1.48(\mathrm{~s}, 18 \mathrm{H}) ;{ }^{13} \mathrm{C}$ NMR $\left(\mathrm{CDCl}_{3}\right) \delta 157.4,154.4 .151 .0 .132 .7,128.0,126.4 .122 .7$. 76.9. 54.0. 52.2, 27.8. EIMS $m z$ (rel intensity) $396\left(\mathrm{M}^{+} .2\right)$. $340(10), 284(38), 153(47), 57(100)$.

2-Chloro-5,7-dihydro-pyrrolo $[3,+-b]$ pyridine-6-carboxamidine (12). To a solution of 11 (226 $\mathrm{mg} .0 .57 \mathrm{mmol}$ ) in trifluoroacetic acid $(4 \mathrm{~mL})$ was added a few drops of triethylsilane. The reaction mixture was allowed to stir for $30 \mathrm{~min}$ and the solution was evaporated to dryness to give a residual solid. The solid was collected by filtration. washed with diethyl ether, and dried in vacto to yield $86.4 \mathrm{mg}(77 \%)$ of $12 . \mathrm{mp} 240^{\circ} \mathrm{C}:{ }^{1} \mathrm{H}$ NMR (DMSO- $\left.c_{6}\right) \delta 7.92(\mathrm{~s}, 2 \mathrm{H}), 7.81$ (d. $J=6.1 \mathrm{~Hz}, \mathrm{lH}$ ). 7.37 (d. $J=8.1 \mathrm{~Hz}, \mathrm{lH}) .7 .16(\mathrm{~s}, \mathrm{lH}$ ), $4.80(\mathrm{~d}, J=10.4 \mathrm{~Hz}, 4 \mathrm{H}):{ }^{13} \mathrm{C}$ NMR (DMSO- $\left.c_{6}\right) \delta 156.1$, 155.1, 150.4. 133.9, 127.9. 123.0, 52.4. 50.8, EIMS $m z$ (rel intensity) $196\left(\mathrm{M}^{+} .40\right) .153(100), 117(35), 69(30)$.

Acknowledgement. We thank the Ministry of Science \& Teclunology, Korea. for financial support (KO-9903-03).

\section{References}

1. Badio. B.: Daly. J. W. Hol Phamacol 1994, 45, 563 .

2. Holladay: M. W: Wasicak. J. T.: Lin. N.-H.: He Y.: Ryther. K. B. Bannon. A. W: Buckley. M. I.: Kim. D. I. B.: Decker. M. W.: Andersont. D. T.: Campbell. J. E.: Kuntzweiler. T. A.: DonnellyRoberts. D. L.; Piattoni-Kaplan, M: Briggs, C. A.: Williams, M: Arneric. S. P. J.lled Chem. 1998, 11.407

3. Moriya K. Shibuta, K.: Hattori. Y.: Tsuboi, S.-i.: Shiokawa. K.: Kagabu. S. Biosci. Biotech Biochem 1992. 56.364.

4. Ma. J. C.: Dougherty. D. A. Chent. Ren: 1997. 97. 1303.

5. Schmit. T. D.: Sharpless. C. G. V.: Caldwell. W. S. J. Med Chent. 1999. +2,3066.

6. For representative examples on the synthesis of halide-containing pyridine dicarboxylic acids. see: (a) Lindenstruth, A. F.: Vanderwerf. C. A. J. Am. Chem. Soc. 1949. 71. 3020. (b) Gadekar. S. M.: Fredereck. J. L.: Semb. J.: Vaughan1. J. R.. Tr. J. Org. Chem. 1961. 26. 468. (c) Cochrant. J. C.: Little. W. F. J. Ong. Chem. 1961. 26 808. (d) Mongin, F.; Trécourt. F.: Queguiner, G. Tetrahtedon Leth 1999. 40,5483

7. For the ruthenium tetroxide oxidation of aromatic compounds. see: (a) Piatak. D. M.: Herbst. G.: Wicha. T.: Caspi. E. J. Org. Chent 1969. 34. 116. (b) Ayres. D. C.: Hossain. A. M. M. J. Chent Soc. Perkin Trans. I 1975. 707. (c) Carlsen. P. H. T.: Katsuki. T: Martin. V. S.; Sharpless. K. B. J. Org. Chem. 1981. 46. 3936. (d) Kasai. M.: Ziffer, H. J. Org. Chem. 1983. 48,2346 (e) Nuñez. M. T.; Martín. V. S. J Org. Chem. 1990. 55. 1928.

8. (a) Le Bas. M.-D.: Guéret. C. C.: Perrio. C.: Lasne. M.-C.: Barré. L. Swnthesis 2001. 2495 (b) Cho. K.-N.: Park. M.-S.: Shim. Y.-K.: Lee K.-I. Bull. Korean Chem. Soc. 2002. 23. 1830.

9. For the reduction of pyridine analogs. see: (a) Ziegler. F. E. Sweeny, J. G. J. Org. Chem. $1969,34.3545$, (b) Rama Rao. A. V: Yadav. J. S: Valluri, M. Tetrahedron Lett. 1994. 35. 3613. (c) Kim. D. Y.: Jung. I. C.: Lee. J. W: Yoon, G. T. J. Kowan Chem. Soc. 1998.12 .102

10. Narasimhan. S.: Ganeshwar. K.: Madhavan. S. Smth. Conmtm. 1995. 25,1689

11. Feichtinger, K: Sings, H. L: Baker. T. J: Matthews, K. Goodman. M. J. Org. Chem. 1998, 63.8432. 